\title{
Whole Process Investment Control of Power Grid Project Based on Closed-Loop Feedback System
}

\author{
Ning Liaoyi ${ }^{1}$, Liu Dunnan ${ }^{2}$, Liu Jinyuan ${ }^{1}$, Ji Lihang ${ }^{2}$, Wu Xuefeng ${ }^{1}$, Xiu Ce ${ }^{2}$ \\ ${ }^{1}$ State Grid Liaoning Economic Research Institute, Liaoning, Shenyang, China, 110015; \\ ${ }^{2}$ North China Electric Power University, School of Economy and Management, Beijing, China, 102206
}

\begin{abstract}
With the development of economy, the demand of electric power is higher and higher. At the same time, the development of various types of power grid makes the investment of power grid projects more and more, but there is no complete and effective way to monitor the whole process of power grid project. This paper introduces closed-loop feedback system. The investment of power grid project is divided into investment planning and the implementation of investment, and the investment monitoring points are selected. The closed-loop feedback system is used to dynamic monitoring of the whole process. Feedback the investment deviation and enter the next stage to control, correction, etc., so as to realize the investment control of power grid project and reduce the investment risk.
\end{abstract}

\section{Introduction}

With the rapid development of economy, the load of the city is growing rapidly, and the existing distribution network is not enough to meet the requirements. At the same time, the development of smart grid and intelligent power distribution network has become reality, therefore, the construction projects of various types power grid will be more and more. Government investment in power grid construction projects will also be greatly increased. However, due to the characteristics of the large area construction, large investment, long construction period, many participants [1], the investment risk of power grid project is also very large, so the management of the network construction is very high. At present, the management of power network planning is not enough, and the management of power grid construction project is lack of the necessary whole process supervision and management [2]. Therefore it is impossible to ensure the reasonable control of the power grid project investment funds.

Firstly, according to the general engineering project management mode, the paper analyzes the investment monitoring points of power grid project. Secondly, using the closed-loop feedback system to carry out the whole process of power grid project investment supervision, feedback, control, reduce the investment risk of power grid project.

\section{The selection of the power grid project whole process monitoring points}

\subsection{Selection principle}

(1)The principle of clarity [3]

In the process of investment control point selection, the clear structure and selection criteria need to be paid attention.

(2)The principle of scientific and objective

In the process of investment control point selection, it must fully consider the various stages of the whole life cycle of power grid project investment structure and control characteristics.

(3)The principle of versatility and maneuverability
When the investment monitoring point selection, the selected monitoring points should be able to apply to any one power grid project; at the same time, the choice of investment monitoring point, can monitor the entire project investment, while the actual value of the monitoring points are available, you can operate.

(4)The principle of Quantitative

In the process of investment control point selection, due to the investment control from the investor's point of view, the monitoring points selected should be a time point or a stage of the cost item, it has the quantitative principle, can measure the digital.

(5)The principle of stability and flexibility

Because of the specific circumstances of different power grid project in different project. Firstly, considering the characteristics of the general power grid project as a stable monitoring point; secondly, to consider the characteristics of different power grid projects and to select a special representative of the cost items, the flexibility of each project has its own value.

(6) The principle of independence

In the process of investment control point selection, to choosing the independence monitoring points which name is cost items.

\subsection{Whole process monitoring points of power grid project}

(1)The general engineering key investment monitoring site selection

For the whole process of investment management, it is essential to plan the investment control of every link. With the continuous development of China's economy, the project investment main body to reduce investment costs and improve investment income requirements continue to increase. General project of the whole process of investment management process ${ }^{[4]}$ as shown in figure 1. 


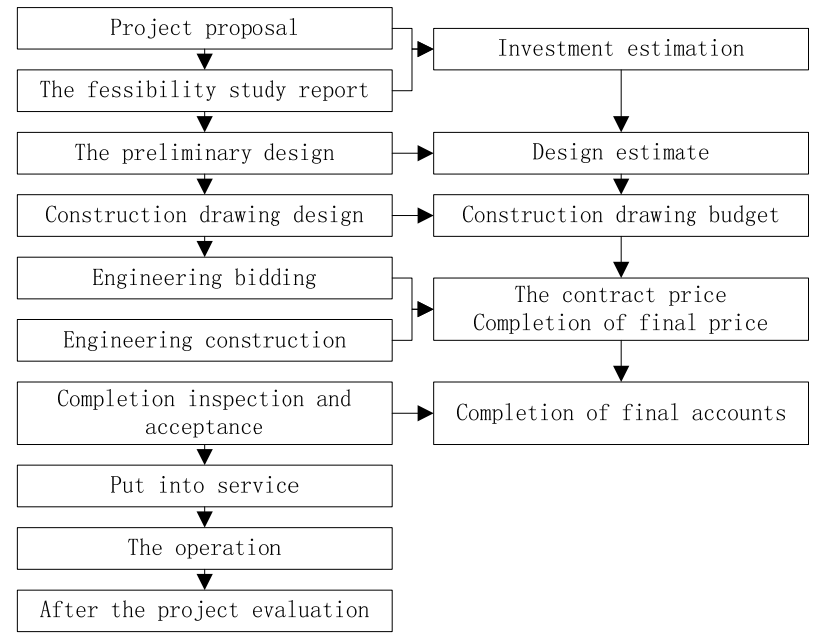

Figure 1 Whole process cost management flowchart

As a result, the investment estimation, feasibility study report, preliminary design budget, construction budget and final accounts of the project proposals are the important investment monitoring points of project management.

(2)Selection of investment monitoring points in the actual construction phase

The above monitoring points are planned or completed data points, therefore, at this stage needs for more details to select the monitoring point.

At present, the power grid project generally uses the subcontract, the process is: provincial network companies to prepare feasibility studies and investment estimation and the grid engineering design tasks the contractor to design units, and then the power grid construction tasks contracted out to construction general contractor (General provincial network company under the engineering company) ; Then, the general contractor of construction engineering subcontracting, the main part of the project to the construction contract total package units; part of the construction project contract is generally parallel, some special engineering and procurement of major equipment; the rest is borne directly by the general construction contractor. Therefore, the corresponding investment monitoring points can be divided into two parts, the general contract and the parallel contracting.

1) Part of the total project investment monitoring point selection

In the general contract, the general contract is made up of the substation installation contract, the substation construction contract, power transmission line project contract and so on. Taking into account that which can be redesigned and adjusted, so that the total cost of investment monitoring points as shown in table1.

\section{Table 1 Part of the total contract investment monitoring point}

\begin{tabular}{cl}
\hline $\begin{array}{c}\text { Monitory } \\
\text { point } \\
\text { number }\end{array}$ & \multicolumn{1}{c}{\begin{tabular}{c}
\multicolumn{1}{c}{ The name of investment } \\
monitory point
\end{tabular}} \\
\hline & $\begin{array}{l}\text { the general contract } \\
\text { the substation installation contract }\end{array}$ \\
1 & the main equipment installation project contract \\
2 & auxiliary equipment installation project contract \\
3 & sub system debugging and the whole set of starting \\
& test run cost \\
4 & substation construction engineering contract \\
5 & The main structure construction engineering contract \\
& Housing construction project contract \\
6 & Transmission lines engineering contract \\
7 & Transmission lines construction engineering contract \\
8 & Basic project cost \\
9 & general contract project change, claim, material, etc \\
10 & Project construction technical services cost \\
11 & Measures fee \\
12 & Production preparation fee \\
13 & Management and supervision fee \\
14 & three accesses and site leveling cost \\
15 & Government fee \\
16 & Land cost \\
17 & Other cost \\
\hline
\end{tabular}

2) the selection of the monitoring points of the investment in the parallel contracting

Parallel contracting part mainly composition by the investors designated contracting part of project cost, the investors designated supply parts procurement cost, construction and installation engineering design part. Taking into account that which can be redesigned and adjusted. Therefore, the investment monitoring points of the parallel contracting section are shown in Table 2.

Table 2 Parallel contracting part investment monitoring points

$\begin{array}{cc}\text { Monitory } & \text { The name of investment } \\ \text { point } & \text { monitory point } \\ \text { number } & \end{array}$

The investor designated contract construction contract

Precipitation, excavation and slope protection

1 engineering cost

2 Fire protection engineering contract

3 Environmental protection and water and soil

3 protection engineering contract

4 Labor safety and industrial hygiene project contract The investor designated supply contracts

5 The main transformer system purchase contract

6 Distribution equipment purchase contract

7 Reactive power compensation system purchase contract 
8 Communication system purchase contract

9 Other possible professional subcontract

10 Investor to specify the subcontract change

Construction and installation project design contract

11 Construction and installation project design contract

12

Comprehensive office building decoration design

contract

13

Building decoration design contract

\section{Feedback control of the whole process of power grid project based on feedback control system} control

(1)The basic theory of the full closed-loop feedback

For power grid engineering, the whole process of the investment control feedback control is concerned, each link in the whole process of the power grid project and every important investment node is essential and irreplaceable. General project cost management process as shown in figure 1.

At present, there is a lack of systematic and continuous investment in the investment of power grid projects, such as the initial budget, construction budget and settlement, so it is necessary to carry out the whole process investment control system, and then improve the investment management level.

The whole process investment control model based on the closed-loop feedback system is a brand new project investment management model. In this mode, the entire process of power grid project investment management must be timely feedback, adjust and control.

The whole process of the closed-loop feedback system of investment control process as shown in figure 2 :

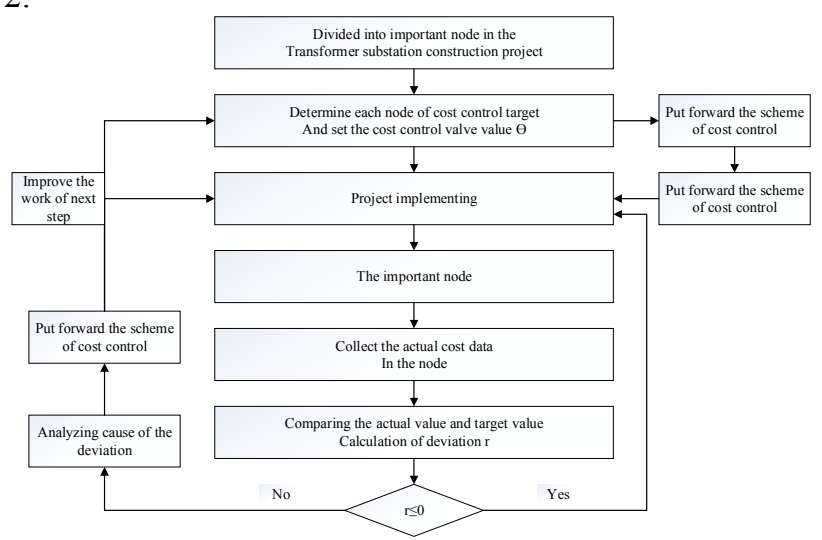

Figure 2 The whole process of the closed-loop feedback cost control process
(2)The key control points of the power grid project each stage

According to the connection and cooperation between the various stages of the power grid project, we need to identify the important control points in each stage of the power grid project, so as to better control the engineering cost of each stage.

(3)Closed-loop feedback cost control of important control points

In view of the important control points in the whole process of power grid project investment, the investment objectives of the control point should be determined before construction, and the investment deviation can be set up.

In the actual operation, according to the collected project implementation process has completed the important control point of the actual investment data, comparison the actual data and the investment target value, to calculate the corresponding investment deviation, and to analysis the control point for the investment deviation, such as (formula 1 ):

$r=\frac{a-p}{p}$

In the formula:

$r$ - Investment deviation;

$a$-Actual investment data of control points;

$p$ _ The target value of the control point.

Investment deviation control rules are followed:

Compare the deviated threshold of cost control with actual deviation at the important control points in various stages of the whole grid projects, we can conclude that the actual investment which has already completed at the important control points is still under control if the deviation is below or equal to the threshold, and implement the project as planned; While the deviation is greater than the threshold, we can conclude that the actual investment which has already completed at the important control points has went beyond the anticipation, as well as the critical control point, now it's necessary to take certain remedial measures to reduce investment, otherwise the investment risk of the project will increase.

\section{Examples of calculation}

Taking a power grid project as an example, the whole process investment control of power grid project is carried out.

The monitoring value and actual value of the major investment monitoring points for this project are shown in table 3 . 


\begin{tabular}{ccrrrr}
\hline Monitory point & $\begin{array}{c}\text { Investment } \\
\text { estimation in the } \\
\text { project proposal }\end{array}$ & $\begin{array}{c}\text { Investment } \\
\text { estimation in } \\
\text { feasibility study } \\
\text { report }\end{array}$ & $\begin{array}{c}\text { Estimate of } \\
\text { preliminary design }\end{array}$ & $\begin{array}{c}\text { Construction } \\
\text { drawing budget }\end{array}$ & $\begin{array}{c}\text { Completion of final } \\
\text { accounts }\end{array}$ \\
\hline Planned value & 150000 & 150000 & 135000 & 135000 & 135000 \\
The actual value & 155000 & 148000 & 125580 & 124000 & 123790 \\
Deviation rate & $3.33 \%$ & $-1.33 \%$ & -6.98 & $-8.15 \%$ & $-8.3 \%$ \\
\hline
\end{tabular}

As shown in Table 3, the total process of a power grid project investment plan value and actual value to use the quota design idea in the project investment stage. Therefore, the actual value must not be greater than the planned value. In the project proposal stage, the actual value of the investment estimate is greater than the planned value. In the next stages of planning, as far as possible to reduce the requirements of the plan. In the stage of the feasibility study report, it reduce the requirements of not more than the planned investment estimation. The preliminary design budget and the construction drawing budget, which meet the requirements.

In the actual construction stage, the plan and the actual value of the major investment monitoring points are changed. In the implementation phase of the monitoring point of the project value source is the project's funds use plan. In the implementation phase of the actual value of the monitoring point is the project investment funds in accordance with the plan for the use of funds to pay the situation. The threshold of the implementation phase is obtained by using the method of historical data computation.

According to the historical data of similar projects in the project area, the calculation results of the project payment risk in the range of one million yuan are shown in Table 4. In practical work, we can change the confidence interval flexible of severe feedback, moderate feedback and the feedback.

Table 4 Warning condition distribution interval (Unit: Ten thousand yuan)

\begin{tabular}{|c|c|c|}
\hline Warning condition & Situation & Range \\
\hline \multirow{2}{*}{$\begin{array}{l}\text { No deviation } \\
\text { feedback }\end{array}$} & $\begin{array}{c}\text { Payments over } \\
\text { budget }\end{array}$ & $0 \sim 12$ \\
\hline & $\begin{array}{c}\text { Payments low } \\
\text { budget }\end{array}$ & $0 \sim 10.5$ \\
\hline \multirow{2}{*}{ Mild feedback } & $\begin{array}{c}\text { Payments over } \\
\text { budget }\end{array}$ & $12 \sim 14.5$ \\
\hline & $\begin{array}{c}\text { Payments low } \\
\text { budget }\end{array}$ & $10.5 \sim 12.5$ \\
\hline \multirow{2}{*}{ Moderate feedback } & $\begin{array}{c}\text { Payments over } \\
\text { budget }\end{array}$ & $14.5 \sim 17$ \\
\hline & $\begin{array}{c}\text { Payments low } \\
\text { budget }\end{array}$ & $12 \sim 14.5$ \\
\hline \multirow{2}{*}{ Severe feedback } & $\begin{array}{c}\text { Payments over } \\
\text { budget }\end{array}$ & $17 \sim \infty$ \\
\hline & $\begin{array}{c}\text { Payments low } \\
\text { budget }\end{array}$ & $14.5 \sim \infty$ \\
\hline
\end{tabular}

In the implementation phase, according to the actual project progress of the project value and the actual value of the investment to comparison and correspond correction.

\section{Conclusion}

In this paper, the closed-loop feedback system is introduced to monitor the whole process of power grid project, and the dynamic supervision and feedback of the whole process investment is carried out in two cases. The research of this paper is to provide a certain monitoring method for power grid project investment, to provide effective control risk for the continuous growth of power grid investment, and hope this research can provide reference for future research and application.

\section{Reference}

[1] Hui Chen. Research on Cost Control of Distribution Network Engineering Project [D]. North China Electric Power University, 2013.

[2] Jiawei Sun. Study on the Construction of Smart Distribution Power Grid in Core Area of Baoding City [D]. North China Electric Power University, 2014.

[3] Dan Li. Research on Problem of Engineering Project Total Cost Management \& Countermeasures [D]. Xi'an: Xi'an University of Science and Technology,2009

[4] Xiaodong Zou. A Study of Key Links in Implementation Phase Cost Control of Construction Engineering [D].Chengdu: Sichuan University, 2006 